\title{
転移性骨腫瘍の核医学診断・治療を目的とした薬剤の開発研究
}

\author{
小川数馬
}

\section{Development of Radiopharmaceuticals for Diagnosis and Therapy of Metastatic Bone Cancer}

\author{
Kazuma Ogawa \\ Graduate School of Medical, Pharmaceutical and Health Sciences, Kanazawa University; \\ Kakuma-machi, Kanazawa, Ishikawa 920-1192, Japan.
}

(Received July 3, 2012)

\begin{abstract}
Rhemium-186-1-hydroxyethylidene-1,1-diphosphonate ( $\left.{ }^{186} \mathrm{Re}-\mathrm{HEDP}\right)$ has been used for the palliation of metastatic bone pain. However, delayed blood clearance and high gastric uptake of radioactivity have been observed upon injection, due to the instability of ${ }^{186} \mathrm{Re}-\mathrm{HEDP}$. We designed, synthesized and evaluated a stable ${ }^{186} \mathrm{Re}$-mercaptoacetylglycylglycylglycine (MAG3) complex-conjugated bisphosphonate, [[[[(4-hydroxy-4,4-diphosphonobutyl) carbamoylmethyl] carbamoylmethyl] carbamoylmethyl] carbamoylmethanethiolate] oxorhenium (V) (186Re-MAG3-HBP). The stability of ${ }^{186} \mathrm{Re}-\mathrm{MAG} 3-\mathrm{HBP}$ and ${ }^{186} \mathrm{Re}-\mathrm{HEDP}$ in phosphate buffer were compared. No measurable decomposition of ${ }^{186} \mathrm{Re}-$ MAG3-HBP occurred, while only approximately $30 \%$ of ${ }^{186}$ Re-HEDP remained intact 24 hours post-incubation. In biodistribution experiments, the radioactivity level of ${ }^{186} \mathrm{Re}-\mathrm{MAG} 3-\mathrm{HBP}$ in bone was significantly higher than that of ${ }^{186} \mathrm{Re}-$ HEDP. Blood clearance of ${ }^{186}$ Re-MAG3-HBP was faster than that of ${ }^{186}$ Re-HEDP. In addition, the gastric accumulation of ${ }^{186} \mathrm{Re}-\mathrm{MAG} 3-\mathrm{HBP}$ radioactivity was lower. To evaluate the therapeutic effects of ${ }^{186} \mathrm{Re}-\mathrm{MAG} 3-\mathrm{HBP}$, an animal model of bone metastasis was prepared. In the rats treated with ${ }^{186} \mathrm{Re}$-HEDP, tumor growth was comparable to that in untreated rats. In contrast, when ${ }^{186} \mathrm{Re}-\mathrm{MAG} 3-\mathrm{HBP}$ was administered, tumor growth was significantly inhibited. Bone pain was attenuated by treatment with ${ }^{186}$ Re-MAG3-HBP or ${ }^{186}$ Re-HEDP, but ${ }^{186}$ Re-MAG3-HBP tended to be more effective. These results indicate that ${ }^{186}$ Re-MAG3-HBP could be useful as a therapeutic agent of metastatic bone pain. Moreover, based on the similar concept, we designed, synthesized, and evaluated a ${ }^{99 \mathrm{~m}} \mathrm{Tc}$-6-hydrazinopyridine-3-carboxylic acid-conjugated bisphosphonate $\left({ }^{99 \mathrm{~m}} \mathrm{Tc}-\mathrm{HYNIC}-\mathrm{HBP}\right)$ as a bone scintigraphic agent. ${ }^{99 \mathrm{~m}} \mathrm{Tc}-\mathrm{HYNIC}-\mathrm{HBP}$ gave higher levels of radioactivity in bone than ${ }^{99 \mathrm{~m} T c-H M D P}$. There was no significant difference in clearance from blood between ${ }^{99 \mathrm{~m}} \mathrm{Tc}-\mathrm{HYNIC}-\mathrm{HBP}$ and ${ }^{99 \mathrm{~m}} \mathrm{Tc}-\mathrm{HMDP}$. Consequently, ${ }^{99 \mathrm{~m}} \mathrm{Tc}-\mathrm{HYNIC}-\mathrm{HBP}$ showed a higher bone-to-blood ratio than ${ }^{99 \mathrm{~m}} \mathrm{Tc}-\mathrm{HMDP}$. The findings indicate that ${ }^{99 \mathrm{~m}} \mathrm{Tc}-\mathrm{HYNIC}-\mathrm{HBP}$ holds great potential for bone scintigraphy.
\end{abstract}

Key words_— bone metastasis; radiopharmaceutical; palliation; bone scintigraphy; internal radionuclide therapy

\section{1. はじめに}

前立腺がん，乳がんなどのがんは骨に転移し易 く，その多くは激しい痛みを伴うために患者の quality of life は著しく損なわれる。この疼痛の緩 和のための治療法として，副作用が少なく，1回の 投与で複数の部位に長期間の効果が期待できる，放 射性薬剂を用いた内部照射療法（内用療法）が期待 され，その薬剤の1つとして，2007 年に国内でも

The author declares no conflict of interest.

金沢大学大学院医薬保健学総合研究科（T920-1192 金 沢市角間町)

e-mail: kogawa@p.kanazawa-u.ac.jp

本総説は, 平成 23 年度日本薬学会北陸支部学術奨励賞

の受賞を記念して記述したものである.
${ }^{89} \mathrm{Sr}$ （塩化ストロンチウム：メタストロン）が承認 され成果をあげている.11)この内用療法に用いる放 射性薬剂としていくつかの化合物が検討されている が，中でも rhenium-186 ( ${ }^{186} \mathrm{Re}$, 半減期 91 時間) の標識化合物は, ${ }^{186} \operatorname{Re}$ が治療に適した $\beta^{-}$線と診 断に適した $\gamma$ 線を同時に放出することから，腫瘍へ の放射能の分布を確認しながら治療することができ る核種としてその利用が注目されている. 実際, こ れまでに，骨に高い親和性を有する化合物，ビスホ スホネートの1つである 1-hydroxyethylidene-1,1diphosphonate (HEDP) と ${ }^{186} \operatorname{Re}$ とが直接配位した 錯体 ${ }^{186}$ Re-HEDP が開発され, 臨床研究が進められ ている。しかしながら， ${ }^{186}$ Re-HEDP は錯体の安定 
性がそしく, 生体内で解離して ${ }^{186} \mathrm{ReO}_{4}^{-}$が生成す るため, 血液クリアランスの遅延, 胃への放射能集 積が起こり, 問題となる。. ${ }^{2,3)}$ そこで, 筆者は, 生体 内で安定，かつ，転移性骨腫瘍の病巣部位に高く集 積する ${ }^{186} \mathrm{Re}$ 標識薬剤を開発するために，骨に高い 親和性を有することが期待されるビスホスホネート 誘導体を母体化合物として，安定な ${ }^{186} \mathrm{Re}$ 錯体を結 合した新規化合物を設計，合成し，評価を行い, ${ }^{4-7)}$ その成果を骨シンチグラフィ用薬剤である ${ }^{99} \mathrm{~m} T \mathrm{c}-$ ビスホスホネート錯体の設計にも応用した. ${ }^{8)}$ 本稿 ではその成果について概説する。

2. 新規放射性レニウム標識薬剤の分子設計・合 成·体内動態の検討

転移性骨腫瘍の内用療法に有効な ${ }^{186} \mathrm{Re}$ 標識薬剂 の設計において重要な点は, 骨への輸送担体である ビスホスホネートの骨への親和性を損なうことなく 安定な ${ }^{186} \operatorname{Re}$ 錯体を導入することである。 そこで, 標的分子への親和性に関与する部位と，それとは独 立して放射性核種を安定に保持する部位とを具備す る二官能性放射性薬剂の概念を応用した薬剤設計を 行うこととした。そして， ${ }^{186} \operatorname{Re}$ の配位子として は，水溶性が高く, ${ }^{186} \operatorname{Re}$ と安定で比較的コンパク 卜な錯体を形成することが知られている $\mathrm{N}_{3} \mathrm{~S}$ 型四 座配位子である mercaptoacetylglycylglycylglycine (MAG3) ${ }^{9)}$ を選択した。一方，ビスホスホネートの P-C-P 部位の炭素に水酸基が結合しているビスホス ホネート誘導体は，水酸基が結合してないビスホス ホネート誘導体と比べて骨への親和性が高いことが 報告されている. ${ }^{10,11)}$ そこで，本研究では，水酸基 が結合しているビスホスホネート誘導体を骨への輸 送担体として用いることとし，ビスホスホネートの 骨への親和性に関与する部位に影響を与えないと考 えられる部位にリンカーを導入し，リンカーと ${ }^{186} \mathrm{Re}-\mathrm{MAG} 3$ 錯体を結合させた化合物 [ [ [ [ (4-hydroxy-4,4-diphosphonobutyl) carbamoylmethyl] carbamoylmethyl ] carbamoylmethyl ] carbamoylmethanethiolate] oxorhenium (V) (186Re-MAG3-HBP, Fig. 1）を設計し，合成を計画した.

MAG3 のチオール基がトリチル基 (Tr-) で保護さ れた前駆体［1-hydroxy-1-phosphono-4-[2-[2-[2-(2tritylmercaptoacetylamino) acetylamino] acetylamino] acetylamino] butyl] phosphonic acid (Tr-MAG3-HBP) は，Tr-MAG3 とビスホスホネート誘導体である 4-

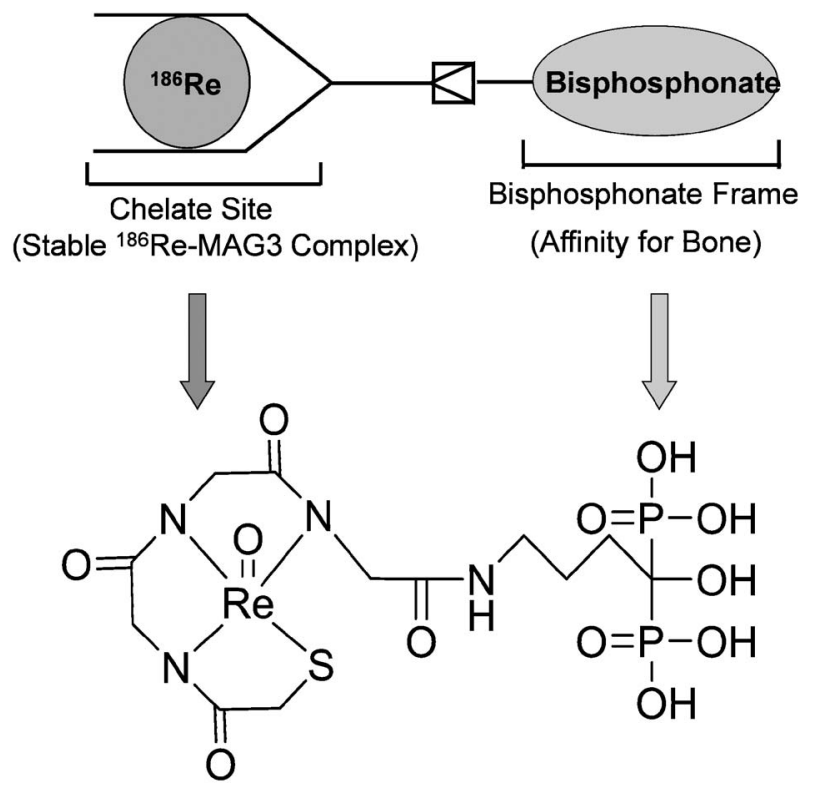

Fig. 1. Concept of Bifunctional Radiopharmaceuticals for Development of ${ }^{186} \mathrm{Re}$ Labeled Compounds for the Palliation of Metastatic Bone Pain and the Chemical Structure of ${ }^{186}$ ReMAG3-HBP

amino-1-hydroxybutylidene-1-1-bisphosphonate をそ れぞれ合成後，結合させることにより合成した。塩 化トリチルとメルカプト酷酸を出発物質とする $\mathrm{Tr}$ MAG3-HBP の全合成路において総収率は $1.5 \%$ で あった。 ${ }^{186}$ Re-MAG3-HBP の放射標識は，TrMAG3-HBP のトリチル基を 5\%トリエチルシラン 含有 TFA で脱保護後, $\mathrm{SnCl}_{2} \cdot 2 \mathrm{H}_{2} \mathrm{O}$ を還元剂とし て ${ }^{186} \mathrm{ReO}_{4}^{-}$と反応させることにより，放射化学的 収率 $90 \%$, 放射化学的純度 $95 \%$ 以上で ${ }^{186} \mathrm{Re}-$ MAG3-HBP を得ることができた，一方，レニウム はビスホスホネート構造と直接配位する可能性があ る。そこで，非放射性のレニウムを用いた ReMAG3-HBP は，レニウムがビスホスホネート構造 と配位する可能性を排除するために，あらかじめ Re-MAG3 錯体を作製し，その後，ビスホスホネー 卜誘導体と反応させることにより合成した。

MAG3 のチオール基をベンゾイル基で保護した BzMAG3 を出発物質とする Re-MAG3-HBP の全合成 路において総収率は $2.3 \%$ あっった。 ${ }^{186}$ Re-MAG3HBP と非放射性 Re-MAG3-HBP をそれぞれの逆相 (RP)-HPLC で分析した結果，両者は，同じ保持時 間に溶出された（Fig. 2)。これにより， ${ }^{186}$ ReMAG3-HBP は, 非放射性 Re-MAG3-HBP の化学 構造と同一であり, MAG3 結合ビスホスホネート 
を ${ }^{186} \mathrm{Re}$ 標識した場合， ${ }^{186} \mathrm{Re}$ は MAG3 部位とのみ 錯体を形成することが示された。

${ }^{186} \mathrm{Re}-\mathrm{HEDP}$ と ${ }^{186} \mathrm{Re}-\mathrm{MAG} 3-\mathrm{HBP}$ をリン酸緩衝 液中でインキュベートし，in vitro における安定性 を評価した結果， ${ }^{186} \mathrm{Re}-\mathrm{HEDP}$ は経時的に ${ }^{186} \mathrm{ReO}_{4}^{-}$ への分解が認められ，24 時間後において未変化体 の割合は 30\%以下であった。それに対して， ${ }^{186} \mathrm{Re}-$ MAG3-HBP は，24 時間後においても $95 \%$ 以上が 未変化体として存在した。一方， ${ }^{186}$ Re-HEDP と ${ }^{186}$ Re-MAG3-HBP をマウスに投与したときの体内 放射能分布の結果 (Fig. 3)，両 ${ }^{186} \operatorname{Re}$ 標識化合物 は，投与後速やかに骨に高く集積し，その放射能集 積は長時間保持された。しかしながら, ${ }^{186}$ Re-HEDP では，胃への放射能集積の増加と血液からの放射能 消失の遅延が認められた。一方, ${ }^{186}$ Re-MAG3-HBP は，胃への放射能集積を示すことなく， ${ }^{186} \mathrm{Re}-$
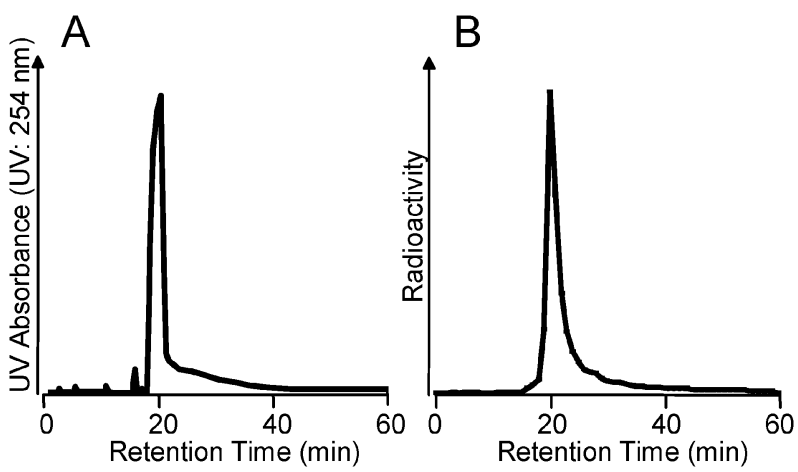

Fig. 2. RP-HPLC Chromatograms of Re-MAG3-HBP (A) and ${ }^{186}$ Re-MAG3-HBP (B) after Purification

Conditions: A flow rate of $1 \mathrm{~mL} / \mathrm{min}$ with $10 \%$ ethanol in $200 \mathrm{~mm}$ phosphate buffer $\mathrm{pH} 6.0$ containing $10 \mathrm{~mm}$ tetrabutylammoniumhydroxide.
HEDP に比べて骨への集積放射能量の増加と速や かな血液からの放射能消失を達成した。一方，非標 的組織である肝臓，腎臓への放射能集積は低值を示 した。したがって，ビスホスホネート構造と独立し て生体内で安定な ${ }^{186} \operatorname{Re}$ 単核錯体形成部位を導入す る分子設計により，生体内における高い安定性が達 成され，その結果， ${ }^{186}$ Re-MAG3-HBP は， ${ }^{186}$ ReHEDP に比べて良好な体内動態を示したと考えら れる.

3. 転移性骨腫瘍モデル動物を用いた ${ }^{186}$ ReMAG3-HBP の治療効果の検討

安定性が高い ${ }^{186}$ Re-MAG3 錯体とビスホスホネー ト分子とを結合した ${ }^{186}$ Re-MAG3-HBP は，高い安 定性に基づく骨への選択的な放射能集積を示し，転 移性骨腫瘍の内用療法を目的とした放射性薬剤とし て有用である可能性を示したため，次に， ${ }^{186} \mathrm{Re}$ MAG3-HBP の治療効果を評価することを目的とし て，ラット乳がん細胞 MRMT-1 を雌性 SpragueDawley ラットの脛骨骨髄腔に移植した転移性骨腫 瘍モデルラット12)を作製し，これを用いて Single Photon Emission Computed Tomography (SPECT) を用いたイメージングによる薬剤の分布挙動, von Frey filament test 及び腫瘍容積測定による薬剤の治 療効果の評価を行った。

186Re-MAG3-HBP の投与 24 時間後の planar 像 とSPECT におけるがん細胞移植部位の断層像であ る transaxial 像の結果（Fig. 4), ${ }^{186}$ Re-MAG3-HBP は，がん細胞移植周辺部位に高く集積することが示 された。一方，左右膝関節にも生理的集積を示した
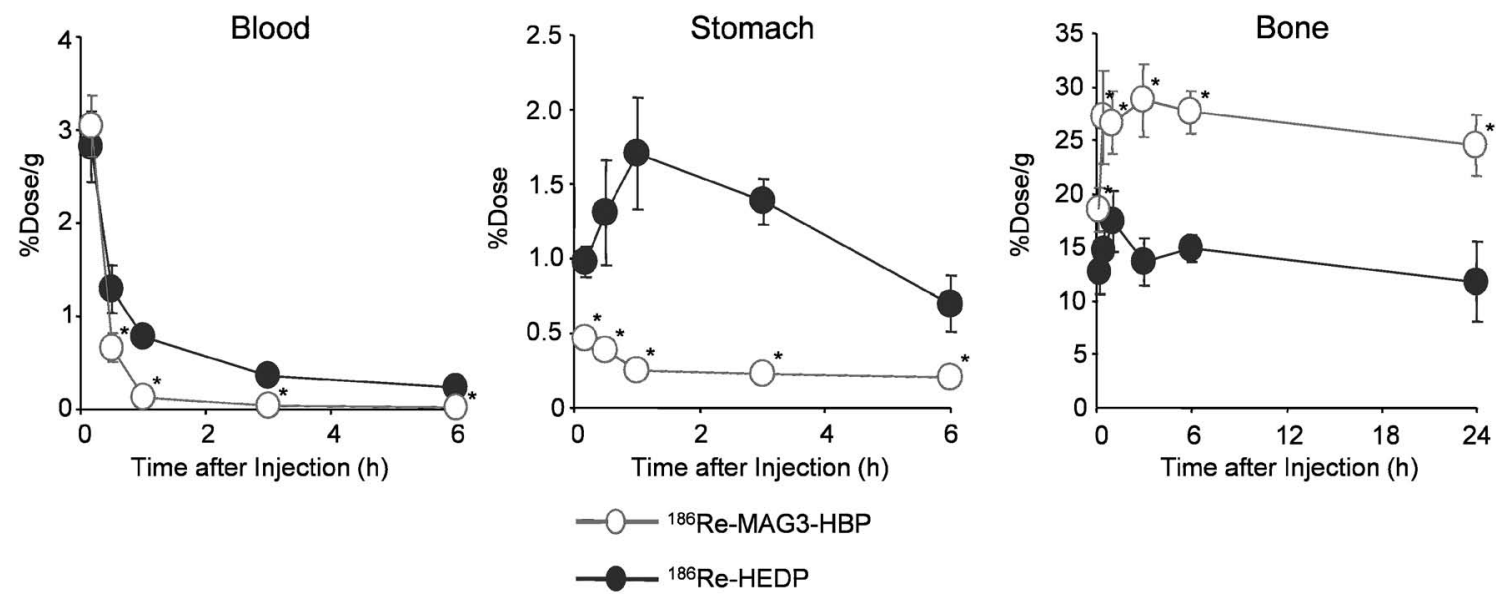

Fig. 3. Biodistribution of Radioactivity after Injection of ${ }^{186}$ Re-MAG3-HBP or ${ }^{186}$ Re-HEDP in Mice Data are expressed as the mean \pm S.D. for five mice. Significance was determined using a Student's $t$ test $\left({ }^{*} p<0.05\right)$ 
A

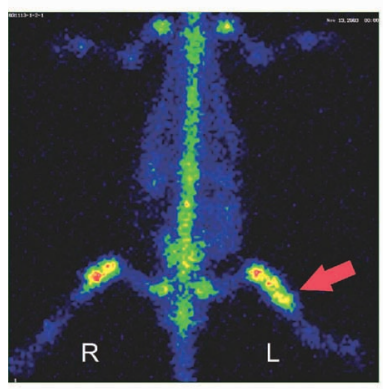

\section{B}

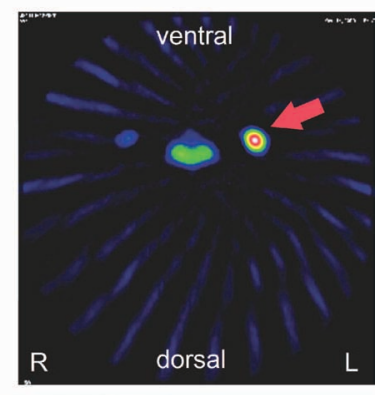

Fig. 4. Planar Image (A) and SPECT Image at Transaxial (B) at $24 \mathrm{H}$ after the Intravenous Injection of ${ }^{186}$ Re-MAG3$\operatorname{HBP}(222 \mathrm{MBq} / \mathrm{kg})$

Arrows indicate the site where tumor cells were injected.

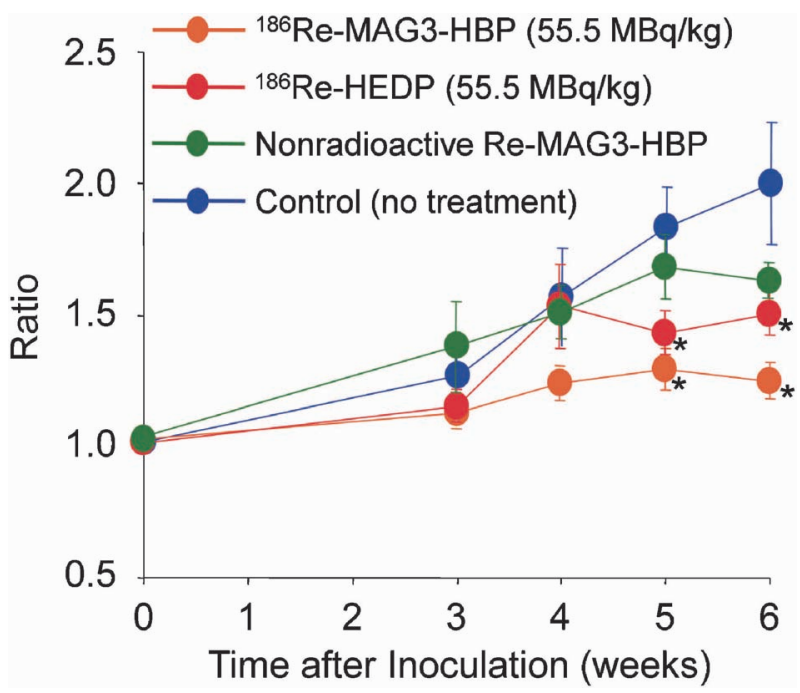

Fig. 5. The Effects of the Radiopharmaceuticals on Bone Cancer Pain

Data are expressed as the ratio of right (contralateral) withdrawal paw threshold values to left (ipsilateral) values (mean \pm S.E.M. for five to seven rats). Significance was determined using a one-way ANOVA followed by Dunnett's post hoc test $\left({ }^{*} p<0.05 v s\right.$. no treatment $)$.

が，骨以外の組織には放射能集積はほとんど観察さ れなかった。疼痛検定である von Frey filament test の結果を Fig. 5 に示す。ここで疼痛の指標として 用いている反応域值の比は，がんによる痛みが大き いほど高值をとる．実験の結果，未治療群において は経時的にこの值は上昇した。それに対して， ${ }^{186}$ Re-HEDP 投与群では，未治療群に対し，反応域 值の比は有意に減少し, 疼痛緩和効果が示された.

一方， ${ }^{186}$ Re-MAG3-HBP においても未治療群に対 して有意な減少を示し，この効果は， ${ }^{186}$ Re-HEDP 投与群よりも強い傾向が観察された（Fig. 5)。腫 瘍容積の経時的変化を Fig. 6 に示す。未治療群に おいては, 腫瘍容積は, 移植 3 週間後から 6 週間後 にかけて顕著な増加を示した。この腫瘍増殖は, ${ }^{186} \mathrm{Re}-\mathrm{HEDP}$ 投与群において，有意な差は観察され なかった。一方， ${ }^{186}$ Re-MAG3-HBP 投与群では， 腫瘍増殖が有意に阻害された。

これまでに，放射線治療による骨腫瘍の疼痛緩和 の機序は完全には明らかになっていないが，放射線 による腫瘍の縮小，若しくは増殖抑制が疼痛緩和の

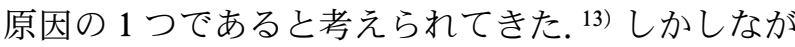
ら，放射線外部照射において，腫瘍致死に必要な線 量に対して，有意に低い線量で疼痛緩和効果が得ら れるといった研究成果が報告されている. ${ }^{14)}$ 本研究 では, ${ }^{186}$ Re-MAG3-HBP と ${ }^{186}$ Re-HEDP の両標識薬 剤はともに疼痛緩和効果を示したが， ${ }^{186}$ Re-HEDP は腫瘍増殖を抑制せずに， ${ }^{186}$ Re-MAG3-HBP は腫 瘍増殖を有意に抑制した。 ${ }^{186}$ Re-MAG3-HBP と ${ }^{186}$ Re-HEDP の腫瘍増殖抑制効果の相違は病巣部位 への放射能集積量の違いに起因しており，その結果，

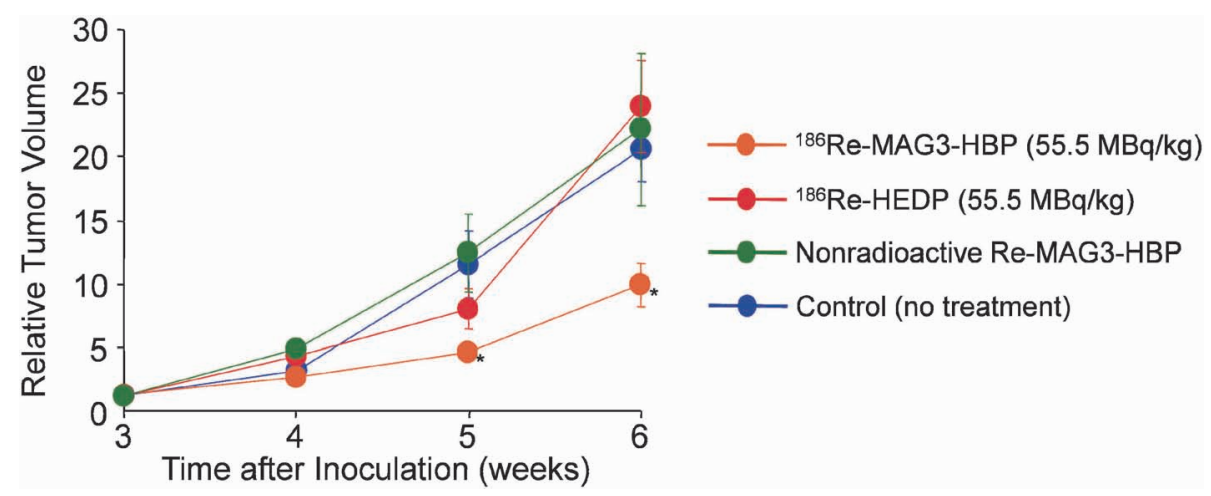

Fig. 6. Curves Depicting Inhibition of the Growth of MRMT-1 on Therapy

Data are expressed as the tumor volume relative to that on the day of treatment (mean \pm S.E.M. for five to seven rats). Significance was determined using a oneway ANOVA followed by Dunnett's post hoc test $\left({ }^{*} p<0.05 v s\right.$. no treatment $)$. 
${ }^{186} \mathrm{Re}-\mathrm{MAG} 3-\mathrm{HBP}$ は腫瘍増殖を抑制することによ って, より強い疼痛緩和効果が得られたものと考え られる。

ビスホスホネートは強力な骨吸収阻害剤であるこ とから, 骨粗鬆症, 高カルシウム血症, そして, 近 年，転移性骨腫瘍の治療にも使用されている。ま た，ビスホスホネートの 1 つであるゾレドロン酸が 転移性骨腫瘍の疼痛緩和に有効であることが, 動物

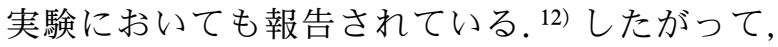
${ }^{186} \mathrm{Re}-\mathrm{MAG3}-\mathrm{HBP}$ の治療効果が ${ }^{186} \mathrm{Re}$ の放出する $\beta^{-}$線でなく, ビスホスホネート構造の薬理作用に 起因している可能性も考えられる。 そこで，非放射 性のレニウムを用い, Re-MAG3-HBP を合成し, 同濃度を単回投与することにより検討を行った。 そ の結果，非放射性 Re-MAG3-HBP 治療群において は，von Frey filament test の反応閾值の比，腫瘍増 殖ともに，未治療群と比べて有意な差は観察されな かった (Figs. 5 and 6). したがって, ${ }^{186}$ Re-MAG3HBP の治療効果は, ビスホスホネート構造に由来 する薬理効果ではなく, ${ }^{186} \operatorname{Re}$ の放出する $\beta^{-}$線に 起因していると考えられる.

4. 骨シンチグラフィ用薬剤 : ${ }^{99 m} \mathrm{mc}$-ビスホスホ ネート錯体への応用

インビボ画像診断用ラジオアイソトープとして優 れた性質を有する technetium-99m ( $\left.{ }^{99 m} \mathrm{Tc}\right)$ と methylene diphosphonate (MDP), hydroxymethylene diphosphonate (HMDP) などのビスホスホネート との錯体は，生体内において骨への高い集積性を示 し，骨関連の病態変化を敏感に感知できることか ら，転移性骨腫瘍を中心とした骨疾患の核医学画像 診断に頻用されている。しかし，これらの薬剤は， 投与後，撮像開始まで 2-6 時間の時間を要すること から，患者の負担，及び診断の効率化の点から，よ り短時間でのイメージングが可能な ${ }^{99 \mathrm{~m}} \mathrm{Tc}$ 標識骨核 医学診断用放射性薬剂の開発が臨床的に強く望まれ ている. 15) 核医学画像診断において重要な点は，標 的組織と非標的組織との放射能集積の比である. そ こで本研究では，投与早期において，高い標的組織 と非標的組織との集積比が得られる ${ }^{99 \mathrm{~m}} \mathrm{Tc}$ 標識化合 物の開発を目的として, 前述した ${ }^{186}$ Re-MAG3-HBP の Reを Tc に置換した ${ }^{99} \mathrm{~m}$ Tc-MAG3-HBP を作製 し, 評価した。

99mTc-MAG3-HBP は Tr-MAG3-HBP のトリチル
基を脱保護後， ${ }^{99} \mathrm{TcO}_{4}^{-}$を反応させることにより， 放射化学的収率 $73 \%$, 放射化学的純度 $95 \%$ 以上で 得た。 ${ }^{99 m}$ Tc-MAG3-HBP のラットにおける体内放 射能分布を調べたところ，臨床で使用されている 99mTc-HMDP と比べて, 骨への集積は向上したも のの，血液からのクリアランスが遅延したため，標 的組織と非標的組織との集積比の指標である骨/血 液比の向上には至らなかった。99m Tc-MAG3 錯体は 血中において高いタンパク結合率を示すことが報告 されていることから， ${ }^{99 \mathrm{~m} T c-M A G 3-H B P}$ の血液か らクリアランスが遅延した原因として, ${ }^{99 \mathrm{~m}} \mathrm{Tc}$ MAG3-HBP の高いタンパク結合率が起因している 可能性を考え，骨/血液放射能比の向上には，骨へ の集積性を維持し，かつ，血液からの放射能消失を 促進させるために，タンパク結合性の低い配位子を 用いた分子設計が必要であると考えた。そこで， 99m Tc と安定な錯体を形成し，さらにタンパク結合 性が 99mTc-MAG3 より低い可能性が考えられる6hydrazinopyridine-3-carboxylic acid（HYNIC）を選 択し，薬剤設計を行った。 Hydrazinopyridine はヒ ドラジル基の窒素とピリジン環の窒素を配位原子と し, ${ }^{16)}$ そのキレート形成には co-ligand として 2 分 子の tricine を必要とする。一方, Liu らは, イミン 窒素含有複素環化合物を tricine とともに co-ligand （L）として用いることにより，Tc：HYNIC：tricine $: \mathrm{L}=1: 1: 1: 1$ の組成で新たな混合配位子錯 体が形成することを報告している.17）また，これま でに小野らは ${ }^{99 \mathrm{~m} T \mathrm{c}}$ の配位に co-ligand として tricine 1 分子をピリジン誘導体へ置換することが，血 漿高分子との配位子交換反応を抑制し，血液クリア ランスを促進すること，また，肝リソソーム内因子 との配位子交換反応を抑制し, 肝集積性を軽減させ ることを報告している. ${ }^{18,19)}$ そこで，ピリジン誘導 体として 3-acetylpyridine（AP）を選択し, AP と

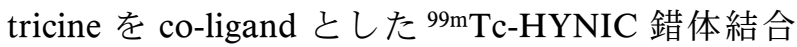
ビスホスホネート, ${ }^{99 m}$ Tc-HYNIC-HBP の合成, 評 価を行った。 ${ }^{99 m}$ Tc-HYNIC-HBP は［4- [ [6- (tertbutoxycarbonyl) -hydrazinopyridine-3-carbonyl] amino]-1-hydroxy-1-phosphonobutyl] phosphonic acid （Boc-HYNIC-HBP）の Boc 基を脱保護後, tricine, 3-acetylpyridine, ${ }^{99} \mathrm{TcO}_{4}^{-}$と反応させることによ り，放射化学的収率 39\%，放射化学的純度 $95 \%$ 以 上で得た。 
キレート部位のタンパク結合率を評価するため,

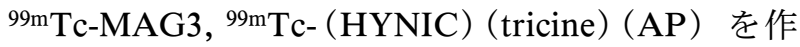
製し，in vivo におけるタンパク結合率を評価した

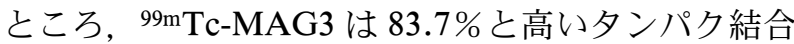
率を示したが， ${ }^{99 m}$ Tc- (HYNIC) (tricine)（AP） は

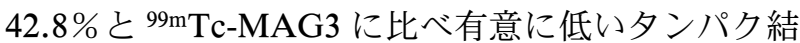
合率を示した。この結果から HYNIC-HBP の ${ }^{99 \mathrm{~m} T \mathrm{c}}$ 放射性標識体においても，99mTc-MAG3-HBP に比 ベタンパク結合率が軽減することが期待された。つ

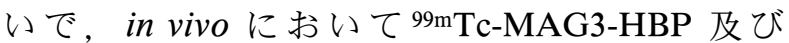
99mTc-HYNIC-HBP のタンパク結合率を評価したと ころ，錯体形成部位のタンパク結合率の差異を反映 して ${ }^{99 \mathrm{~m} T c-H Y N I C-H B P}$ は $88.7 \%$ と ${ }^{99 \mathrm{~m} T c-M A G 3-}$ HBP の $97.7 \%$ に比べ有意に低值を示した。 そこ で，タンパク結合率と血液クリアランスの関連性を 詳細に検討するため，ラットに薬剤投与後，経時的 に血液を採取し，血液からの放射能消失を調べた結 果， ${ }^{99 \mathrm{~m} T \mathrm{Tc}-H Y N I C-H B P}$ は， ${ }^{99 \mathrm{~m}} \mathrm{Tc}-\mathrm{HMDP}$ と同程度 のクリアランスを示した。 また，in vitroにおいて， 99mTc-HYNIC-HBP, ${ }^{99 m}$ Tc-HMDP をハイドロキシ アパタイト懸濁液とともにインキュベートを行った

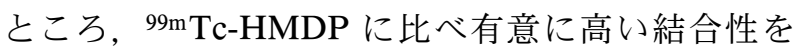

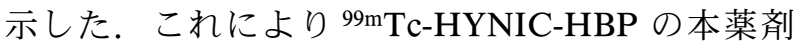
設計に基づくハイドロキシアパタイトへの高い親和 性が示唆された（Fig. 7)。99mTc-HYNIC-HBP のラ

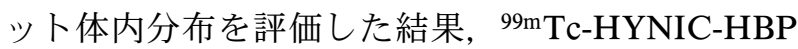

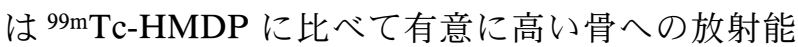

集積性を示し，かつ血液クリアランスは ${ }^{99 \mathrm{~m} T \mathrm{Tc}-}$ HMDP と同程度であったことから，結果として， 99mTc-HMDP に比べ投与早期から有意に高い骨/血 液放射能集積比を達成することに成功した（Fig. 8)。また画像診断を行う際に問題となるような非標 的組織への放射能分布は観察されなかった.

5. おわりに

本研究では，安定な単核錯体結合ビスホスホネー

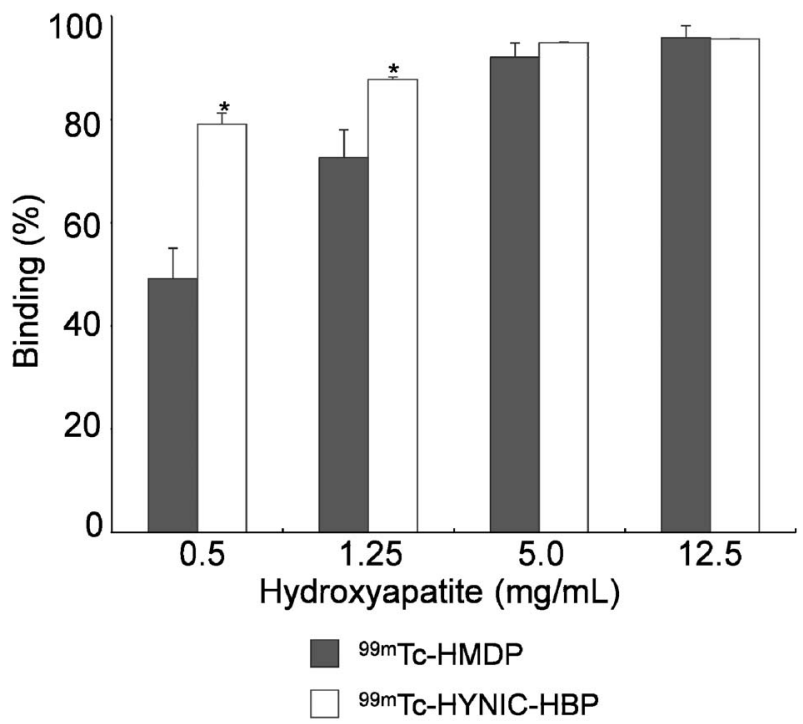

Fig. 7. Binding of ${ }^{99 m} \mathrm{Tc}-\mathrm{HMDP}$ or ${ }^{99 \mathrm{~m}} \mathrm{Tc}-\mathrm{HYNIC}-\mathrm{HBP}$ to Hydroxyapatite

Each column represents the binding of hydroxyapatite to $99 \mathrm{~m}$ Tc-HYNICHBP and ${ }^{99} \mathrm{~m} T \mathrm{Tc}-\mathrm{HMDP}$, respectively. Data are expressed as the mean \pm S.D. for three or four experiments. Significance was determined using a Student's $t$ test $\left({ }^{*} p<0.05 v s .{ }^{99 \mathrm{~m} T c-H M D P}\right)$.

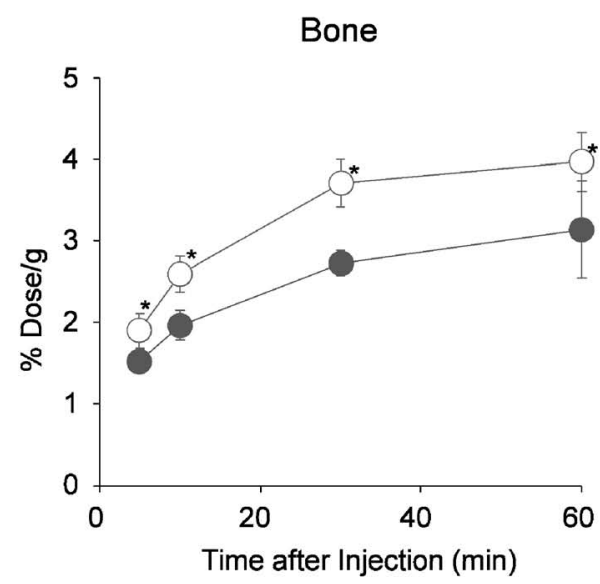

\section{Bone/Blood Ratio}

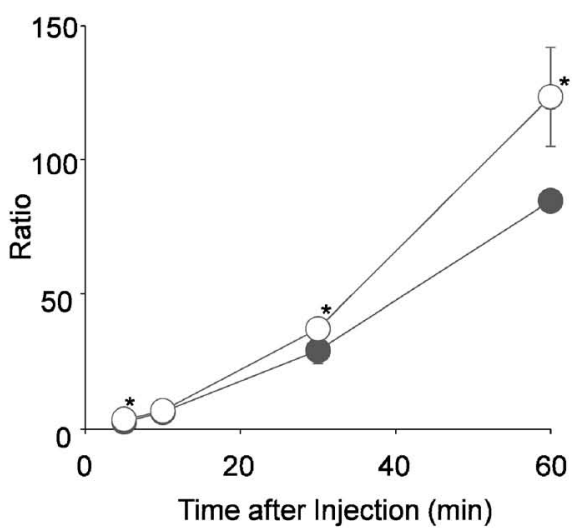

- $99 \mathrm{~m}$ Tc-HMDP

$-\mathrm{O}-99 \mathrm{~m}$ Tc-HYNIC-HBP

Fig. 8. Bone accumulation and Bone/Blood Ratio after Injection of ${ }^{99 \mathrm{~m}} \mathrm{Tc}-\mathrm{HYNIC}-\mathrm{HBP}$ or ${ }^{99 \mathrm{~m} T c-H M D P}$ in Rrats Data are expressed as the mean \pm S.D. for four to six animals. Significance was determined using a Student's $t$ test $\left({ }^{*} p<0.05 v s\right.$. ${ }^{99 m}$ Tc-HMDP $)$. 
トの薬剤設計により, ${ }^{186}$ Re-MAG3-HBP は優れた 体内動態を示し，モデル動物において，単回投与 で, 有意な疼痛緩和効果, 腫瘍増殖抑制効果を示し たことから， ${ }^{186}$ Re-MAG3-HBP は転移性骨腫瘍の 内用療法を目的とした放射性薬剂として有効である 可能性が示された。また，この薬剂設計を骨シンチ グラフィ用診断薬剂に応用した ${ }^{99 \mathrm{~m} T c-H Y N I C-H B P}$ は, 臨床で使用されている ${ }^{99 \mathrm{mTc}-H M D P}$ に比べ投 与早期から有意に高い骨/血液放射能集積比を達成 し，患者の負担，被ばくの軽減及び診断の効率化に 有効である可能性が示された，以上の結果は，転移 性骨腫瘍の診断・治療を目的とした放射性薬㓮の開 発における本薬剤設計の有用性を示し, 今後の薬剤 開発研究に有益な情報を提供するものである.

\section{REFERENCES}

1) Ogawa K., Washiyama K., Curr. Med. Chem., 19, 3290-3300 (2012).

2) De Winter F., Brans B., Van De Wiele C., Dierckx R. A., Clin. Nucl. Med., 24, 898-899 (1999) .

3) de Klerk J. M., van Dijk A., van het Schip A. D., Zonnenberg B. A., van Rijk P. P., J. Nucl. Med., 33, 646-651 (1992).

4) Ogawa K., Mukai T., Arano Y., Hanaoka H., Hashimoto K., Nishimura H., Saji H., J. Labelled Comp. Radiopharm., 47, 753-761 (2004).

5) Ogawa K., Mukai T., Arano Y., Otaka A., Ueda M., Uehara T., Magata Y., Hashimoto K., Saji H., Nucl. Med. Biol., 33, 513-520 (2006) .

6) Ogawa K., Mukai T., Arano Y., Ono M., Hanaoka H., Ishino S., Hashimoto K., Nishimura H., Saji H., Bioconjug. Chem., 16, 751757 (2005).

7) Ogawa K., Mukai T., Asano D., Kawashima
H., Kinuya S., Shiba K., Hashimoto K., Mori H., Saji H., J. Nucl. Med., 48, 122-127 (2007).

8) Ogawa K., Mukai T., Inoue Y., Ono M., Saji H., J. Nucl. Med., 47, 2042-2047 (2006) .

9) Visser G. W., Gerretsen M., Herscheid J. D., Snow G. B., van Dongen G., J. Nucl. Med., 34, 1953-1963 (1993).

10) Meyer J. L., Nancollas G. H., Calcif. Tissue Res., 13, 295-303 (1973).

11) van Beek E., Hoekstra M., van de Ruit M., Lowik C., Papapoulos S., J. Bone Miner. Res., 9, 1875-1882 (1994).

12) Walker K., Medhurst S. J., Kidd B. L., Glatt M., Bowes M., Patel S., McNair K., Kesingland A., Green J., Chan O., Fox A. J., Urban L. A., Pain, 100, 219-229 (2002).

13) Goblirsch M., Mathews W., Lynch C., Alaei P., Gerbi B. J., Mantyh P. W., Clohisy D. R., Radiat. Res., 161, 228-234 (2004).

14) Vakaet L. A., Boterberg T., Int. J. Dev. Biol., 48, 599-606 (2004).

15) Love C., Din A. S., Tomas M. B., Kalapparambath T. P., Palestro C. J., Radiographics, 23, 341-358 (2003).

16) King R. C., Surfraz M. B., Biagini S. C., Blower P. J., Mather S. J., Dalton Trans., 4998-5007 (2007).

17) Liu S., Edwards D. S., Harris A. R., Bioconjug. Chem., 9, 583-595 (1998).

18) Ono M., Arano Y., Mukai T., Uehara T., Fujioka Y., Ogawa K., Namba S., Nakayama M., Saga T., Konishi J., Horiuchi K., Yokoyama A., Saji H., Nucl. Med. Biol., 28, 155164 (2001).

19) Ono M., Arano Y., Mukai T., Fujioka Y., Ogawa K., Uehara T., Saga T., Konishi J., Saji H., Nucl. Med. Biol., 28, 215-224 (2001) . 